İş ve İnsan Dergisi | The Journal of Human and Work

Y1l | Year: Ekim | October 2019

Cilt-Say1 | Volume-Issue: 6 (2)

ss I pp: $145-160$

doi: 10.18394/iid.556161

e-ISSN 2148-967X

http://dergipark.gov.tr/iid/

Araștırma Makalesi

\title{
Liderlikte Ortak Vizyon Oluşturma Davranışının İşletme Performansına Etkisinde Duygusal Zekanın Düzenleyici Rolü
}

\author{
The Moderating Role of Emotional Intelligence on the Effect of Common Vision \\ Creation Behavior in Leadership on Firm Performance
}

\section{Ayşe İpek Koca Balıı ${ }^{a}$ Kemal Can Kılıçc}

\section{MAKALE BİLGİSİ}

Anahtar Kelimeler:

Ortak Vizyon Oluşturma

İsletme Performansı

Duygusal Zeka, Kadın

Girişimciliği, Etkili Liderlik

Davranıșları

Tarihler:

Geliş 19 Nisan 2019

Düzeltme geliș 14 Haziran

2019

Kabul 24 Haziran 2019

\section{ARTICLE INFO}

\section{Keywords:}

Common Vision Creation,

Firm Performance,

Emotional Intelligence,

Women Entrepreneurship,

Effective Leadership

Behaviors

Article history:

Received 19 April 2019

Received in revised form 14

June 2019

Accepted 24 June 2019
ÖZ

Çalışmanın amacı; kadın girişimcilerin etkili liderlik davranışlarından biri olan ortak vizyon oluşturma davranışının işletme performansına etkisinde duygusal zekanın düzenleyici rolü olup olmadığını belirlemektir. Araştırma tanımlayıcı türde tasarlanmış olup gerekli veriler, anket yöntemi ile toplanmıștır. Adana, Mersin, Osmaniye ve Hatay illerinde faaliyet gösteren kadın girişimciler çalışmanın evrenini oluşturmaktadır. Çalışma kapsamında 535 kadın girişimciye anket uygulanmış, anket sonuçları analize tabi tutulmuştur. Araştırma sonucunda, ortak vizyon oluşturma davranışının işletme performansı üzerinde pozitif bir etkiye sahip olduğu görülmüştür. Bununla birlikte ortak vizyon oluşturma davranışı ile işletme performans ilişsisinde duygusal zekanin düzenleyici bir rolü olduğu tespit edilmiştir. Böylece ortak vizyon oluşturma davranışının varllğının duygusal zekanın daha yüksek olduğu durumlarda işletme performansına daha fazla katkı sağladığ ortaya konmuştur.

\begin{abstract}
A B S T R ACT
The aim of the study is to determine whether emotional intelligence has a role in the effect of the common vision creation behaviour, which is one of the effective leadership behaviors of women entrepreneurs, on the firm performance. The research was designed as a descriptive type and the necessary data were collected by survey method. Target population of the study were women entrepreneurs working in Adana, Mersin, Osmaniye. A questionnaire was applied to 535 female entrepreneurs and the results of the survey were analyzed. As a result of the study, it has been determined that the common vision creation behavior has a positive effect on the firm performance. Furthermore, it was found that emotional intelligence tended to moderate the relationship between common vision creation behavior and the firm performance. Thus, it has been shown that the existence of common vision creation contributes more to the firm performance when emotional intelligence is higher.
\end{abstract}

\footnotetext{
a Illetişim kurulacak yazar, Dr. Öğr. Üyesi, Çukurova Üniversitesi, Kozan Isşletme Fakültesi, İşletme Bölümü, Adana, Türkiye. E-mail: ikocaballi@cu.edu.tr.ORCID:0000-0001-7808-5807

b Prof. Dr., Çukurova Üniversitesi, İktisadi İdari Bilimler Fakültesi, İsletme Bölümü, Adana, Türkiye. E-mail: kcan@cu.edu.tr. ORCID: 0000-0003-1248-3321
} 


\section{GİRIŞ}

Sürdürülebilir büyümenin gerçekleşebilmesi, insan merkezli işgücü piyasalarında kadınların ve erkeklerin eşit katılımı yanında, kadınların ekonomik ve sosyal kalkınmanın vazgeçilmez unsuru olarak görülmesinden geçmektedir (Peker \& Kubar, 2012: 173). Toplumsal gelişmişlik düzeyinin ülkeler arası kıyaslanmasında göz önünde bulundurulması gereken en önemli göstergelerden biri kadın ve erkeklerin hak, firsat ve kaynaklara eşit olarak katılıp katılmadığıdır. Kadınların ekonomik ve sosyal yaşama etkin ve erkeklerle eşit oranda katıldığı ülkeler günümüzde "gelişmiş ülkeler" kategorisinde yer alırken, kadınların eğitime, istihdama, karar alma mekanizmalarına eşit oranda katılmadığı ülkelerin hemen hepsi "az gelişmiş" ya da "gelişmekte olan ülke" grupları arasında yer almaktadır (Kadın Erkek Fırsat Eşitliği Komisyonu, 2013). Bu anlamda kadınların işgücüne katılımı, sürdürülebilir gelişmenin önemli bir unsuru olarak hem kuramsal hem de politik açıdan önemli bir husus olarak kabul edilmektir (Evans \& Kelly, 2008: 289).

Son yıllarda, dünyada hızla yaygınlaşan girişimcilik, dünyanın genelinde kabul gören bir faaliyet olmakla birlikte, kadınlara bir istihdam firsatı yaratmakta ve aileleri için de gelir kaynağ olarak görülmektedir. Kaufman Center'a göre mevcut kadın girişimciler ve bunların sayılarındaki artış, küresel pazarda etkin bir biçimde faaliyette bulunmak isteyen herhangi bir ülkenin uzun dönemdeki ekonomik büyümesinin anahtarıdır (Mboko \& Smith-Hunter, 2009: 157). Ülke ekonomisine katkısının yanı sıra kadınların bazı ihtiyaçları da kadın girişimciliğinin yaygınlaşmasına neden olmaktadır. Örneğin kadının kendi ilgi alanı konusunda çalışma isteği, bağımsızlık arayışı, finansal sorumluluklar, konforlu bir yaşam arzusu, bir işle meşgul olma isteği ile yatırım ve istihdam arayışı gibi konular girişimciliği kadınlar için cazip kılmaktadır (Dhillon, 1993: 86).

$\mathrm{Bu}$ çalışmada, kadınların erkeklerden farklı bakış açılarından ve duygu durumlarından yola çıkılarak kadın girişimcilerin liderlikte ortak vizyon oluşturma davranışının, sahip oldukları işletmelerin performanslarına etkisinde duygusal zekanın düzenleyici rolü incelenmektedir.

İşletmelerin başarı sağlayabilmesi ve bu başarılarını uzun vadede devam ettirebilmeleri için etkili liderlik uygulamalarına sahip olmaları gerekmektedir. Liderlik en basit tarifiyle başkalarını, mücadele etmeye değer amaçlar uğruna etkileme ve ilham verme yeteneği olarak tanımlansa da, etkin bir lider başkalarını etkileyecek biçimde vizyon sahibi olmalı, güvenmeli, güvenilmeli, rehber ve önder olmalı, astları ile birlikte olup, onlara sempati ve empati aşılamalı, onlara koçluk yapmalıdır (Sichone, 2004: 9-10). Çalışanların motivasyonunu sağlamak açısından da etkili liderlik işletmeler açısından vazgeçilemez bir faktördür (Waring, 2003: 33). Uzun vadede kalıcı ve yüksek işletme performansı sağlamak isteyen işletmelerin, liderlik stratejilerine odaklanmaları, liderlik kültürü geliştirmeleri ve her kademe yöneticiler için bu gelişimi sürdürmeleri gerekmektedir (Bersin, 2012). Bununla birlikte üst düzey liderlerle ilişkilendirilen vizyon davranışı etkili liderlik sağlamanın bir işareti olarak görülmektedir (Podolny, Khurana \& HillPopper, 2005). Bu anlamda birlikte çalıştı̆̆ personeline liderlik eden kadın girişimcilerin, etkili liderlik davranışlarının da işletme performansı üzerinde etkili olduğu düşünülmektedir.

Çalışmada katılımcıların duygusal zeka ile ilgili özellikleri de incelenmektedir. Duygusal zeka kişinin kendisinin ve başkalarının duygularını kontrol etme, bunlar arasında seçim yapabilme ve kişinin duygularını hayatına yön vermede kullanabilme yeteneğini içeren sosyal zekanın bir şeklidir (Mayer \& Salovey, 1993: 433). Duygular, farklı tepkileri anlama ve daha sonra bu tepkilerle başa çıkma sürecinde kişiye rehberlik edebilmektedir (Alumran \& Punamäki, 2008: 106). Duygusal malzeme özellikle bir sorun olduğunu belirlemek ve bunu çözmek için gerekli ipuçları sağlamakta, çoklu problem çözme bakış açıları geliştirmektedir (Aldea \& Rice, 2006). Bu anlamda etkili liderlik davranışlarından biri olan ortak vizyonun işletme performansına etkisinde duygusal zekanın düzenleyici rolü olduğu düşünülmektedir.

Çalışmanın amacı; etkili liderlik davranışlarından biri olan ortak vizyon oluşturma davranışının işletme performansına etkisinde duygusal zekanın düzenleyici rolü olup olmadığını belirlemektir. $\mathrm{Bu}$ amaçla Adana, Mersin, Osmaniye ve Hatay illerinde faaliyet gösteren kadın girişimciler evren olarak belirlenmiş olup, basit tesadüfi örnekleme yöntemi ile örneklem kitlesi belirlenmiştir. Araştırma tanımlayıcı türde tasarlanmış olup gerekli veriler, anket yöntemi ile toplanmıştır.

\section{KAVRAMSAL ÇERÇEVE}

\subsection{Duygusal Zeka}

Duygusal zeka, duyguları kontrol altında tutabilme, sağlıklı ve uyumlu sosyal ilişkiler kurabilme ve mutlu bir yaşam sürdürebilme için edinilmesi gereken bütün yeteneklerdir (Konrad \& Hendl, 2005: 13). Duygular, düşünce ve eylemleri önemli 
bir şekilde örgütleyen unsurlardır. Her ne kadar bazen çelişkili olsalar da duygular, muhakeme yapmanın ve makul olabilmenin bir gereğidir. EQ (duygusal zeka), önemli sorunları çözmek ya da önemli bir karar vermek gerektiğinde, IQ'nun (bilişsel zeka) yardımına koşmakta ve bunları daha nitelikli ve daha çabuk uygulanmasını sağlamaktadır (Cooper \& Sawaf, 2010).

Duygusal zeka; kendimizle ve çevremizdeki diğer insanlarla başa çıkabilmeyi kolaylaştıran duyguları tanıma, anlama ve etkin biçimde kullanma yeteneğidir. Yani, başkalarının neyi arzuladıklarını, neye ihtiyaç duyduklarını, güçlü ve zayıf yönlerini anlayabilmek, stresle başa çıkabilmek ve insanların çevrelerinde görmek istedikleri gibi biri olmak için duygusal zeka gerekli bir yetkinliktir (Baltaş, 2011: 7). Duygusal zekanın tanımladığı; bireyin kendini tanıması, kontrol etmesi ve güdülemesi, isteklerini erteleyebilmesi, duygusal değişimlerini kontrol etmesi, engellemeler karşısında direnebilmesi, diğer kişilere anlayışla yaklaşabilmesi, onların en içten gelen duygularını anlayabilmesi, etkin ilişkiler kurup sürdürebilmesi yetenekleri, öğrenebilir psikolojik ve sosyal becerilerdir. Birey ancak bu beceriler sayesinde yaşamdaki başarısını ve doyumunu en üst düzeye çıkarabilmektedir (Acar, 2002: 56).

Duygusal zeka, kendimizin ve başkalarının duygularını tanımayı ve değerlendirmeyi öğrenmemizi sağlamakla birlikte duygulara ilişkin bilgileri ve duyguların enerjisini günlük hayatımıza ve işimize etkin bir biçimde yansıtarak uygun tepkiler vermemizi sağlamaktadır (Yeşilyaprak, 2001: 140). Birey duygularını etkin bir şekilde yönetebildiği takdirde, sorunları çözebilmek için en etkili hareketi belirleyebilecek donanıma sahip hale gelmektedir. Bireyin duygusal zekayı algılayabilmesi yaşamında, işlerinde, aile ilişkilerinde ve vatandaşlık görevlerinde gelişmelerine imkan sağlayan mekanizmaları genişletmektedir (Cherniss \& Goleman, 2001: 42).

\subsection{Liderin Ortak Vizyon Olușturma Davranıșı}

Liderlik, belli bir durum içinde, belli bir anda ve belli koşullar altında ve bir grupta; bireylerin örgütsel hedeflere ulaşmak için gönüllü çabalarının teşvik edildiği, belirlenmiş ortak hedeflere ulaşmayı sağlamada aracı olan, deneyimlerin aktarıldığı bir etkileme sürecidir (Werner, 1993: 17). Liderlik davranışı ise, liderin örgütsel amaçlarını gerçekleştirmek amaciyla; grubunu ve iş ortamını, örgütün amaçlarını ve izleyicilerinin motivasyonunu dikkate alarak seçmiş olduğu davranış biçimidir. Herhangi bir tarzı benimsemiş olan liderin, karşılaştığı durumlar karşısında göstereceği davranış, benimsemiş olduğu yaklaşımın bir yansıması olarak karşımıza çıkmaktadır (Hicks \& Gullert, 1981: 234). Liderler, liderlik görevlerini yerine getirirken çok çeşitli tarzlarda davranabilmektedirler ve bu davranış tarzları, örgütlerde, insan kaynağının örgütün amaçlarına ulaşmasında ve bu doğrultuda harekete geçirebilme noktasında önemli bir rol oynamaktadır (Doğan, 2001: 66).

Etkili liderlik "grubun problemlerini çözmek ya da hedeflerine ulaşmak için grubun beklenti ve yeteneklerini başlatan ve sürdüren, üyeler arasındaki etkileşimi sağlamak" olarak tanımlanmaktadır (Bass, 1990: 20). Bununla birlikte etkili liderlik davranışları birçok araştırmaya konu olmuş ve bu çalışmalarda farklı etkili liderlik davranışlarından bahsedilmiștir (Bennis \& Nanus, 1985; Bass, 1985; Tichy \& Devanna, 1986; Yukl, 1989; Pawar \& Eastman, 1997). Bu etkili lidelrik davranışlardan biri de ortak vizyon oluşturma davranıșıdır (Bass, 1985; Bass \& Avolio, 1994; Greenberg, 2002: 281; Andersen, 2006: 1084; DeRue vd., 2011; Carton, Murphy \& Clark, 2014).

Liderlik, ortak bir görevin gerçekleşmesi için bir insanın diğerlerinin yardım ve desteğini sağlaması gereken sosyal bir etki sürecidir (Chemers, 1997: 12). Liderler heyecan verici olasılıkları ve yüksek hedefleri hayal ederek geleceği gözlerinde canlandırmalı ve bu hedefleri gerçekleştirmenin önemini sürekli çalışanlara hatırlatmalıdır. Liderlerin başarılı olması için ortak hedefleri kullanarak herkesin paylaşabileceği bir vizyon yaratıp insanları bu vizyona dahil etmeleri gereklidir. Vizyon, gelecekle ilgili beklentilerin hesaplanabilmesi yeteneğine sahip olunmasıdır ve kişilerin gelecek üzerinde odaklanmalarına yardımcı olur. Vizyon oluşturma örgütsel başarı için zorunlu olup, liderlik davranışının oluşumuna etkili olan unsurlardan bir tanesidir. Bu bağlamda liderin örgüt içerisinde bir vizyona ihtiyacı vardır. Amaç ve yön duygusu olmadan herkesi saran bir heyecan yaratmak zordur (Goleman, Boyatzis \& Mekee, 2002). Bu anlamda lider, vizyonu başkalarıyla paylaşmalı, onları inandırabilmelidir. Ortak bir amaç için çaba göstermenin anahtarı ise, kurulan hayalin herkesin çıkarına olacağını göstermektir (Kouzes \& Posner, 2002).

\subsection{Işsletme Performanst}

Performans, iş yapan bir bireyin, grubun ya da örgütün o işle ulaşılmak istenen hedeflere ulaşma derecesinin nitel ya da nicel etkinliği olarak tanımlanabilmektedir (Denison \& Mishra, 1995; Fisher, 1997; Karakaş \& Ak, 2003: 338). Bu anlamda işletme performansını ise, işletmenin belirli bir zaman dilimi sonunda elde ettiği çıktı ya da çalışmanın sonucu olarak ifade etmek 
mümkündür (Porter, 1991; Akgemci, 2008: 478). Bir sistemin performans1, belirli bir zaman sonucunda elde ettiği çıktı veya çalışmanın sonucudur. $\mathrm{Bu}$ sonuç, işletmenin sahip olduğu amacın veya görevin gerçekleştirilme derecesi olarak anlaşılmalıdır ki, bu durumda performans, işletme amaçlarının gerçekleştirilebilmesi için gösterilen tüm çalışmaların değerlendirilmesi olarak da açıklanmaktadır (Grady, 1991: 49; Akal, 1998: 1; Cokins, 2004: 29).

Performans ölçümü; ürünlerin, hizmetlerin veya işlemlerin gerçekleştirilmesinde, görevlerin nasıl yerine getirileceğinin bir program dahilinde tarafsız olarak ölçülmesi yöntemidir. Performans ölçümü, öz değerlendirmenin, hedef oluşturmanın ve gelişimi izlemenin bir aracı olarak kullanılabilecek analitik bir süreçtir (Demirkaya, 2000: 3). Performans ölçümünün amaçlarını kısaca özetleyen Apaydın (2007: 155)'a göre ise performans ölçümünün amacı; pazar beklentileri ile stratejik hedefler arasında uyumu sağlamak, işletme kaynaklarının etkin kullanılmasını koordine etmek ve daha önce belirlenen stratejik hedeflere ulaşıllp ulaşılmadığını denetlemektir.

Bir işletmenin amaçlarını ne ölçüde gerçekleştirip gerçekleştirmediğini tespit etmek üzere yapılan genel anlamdaki performans ölçme ve değerlendirme çalışmalarında yapılacak ilk işlerden birisi, işletmenin hangi ölçüt ve boyutlar açısından değerlendirileceği sorunudur (Mutlu, 2007: 29). Bu ölçtüler işletmeden işletmelere farklılık gösterdiği gibi zamansal açıdan da değişiklikler göstermiştir. Finansal performans her dönemde işletmelerin önemli bir göstergesi olmuşken; sanayi devrimiyle birlikte verimlilik; bilgi toplumuyla birlikte ise kalite, yenilik, yeni ürün başarısı, itibar gibi kriterler işletme performansı göstergeleri arasında olmuştur. Özellikle bilgi çağıyla birlikte işletme başarısında finansal ve maddi varlıklarla birlikte bilgiye bağlı maddi olmayan varlıklar da önem kazanmıştır (Venkatraman \& Ramanujam, 1986; Emrem, 2002: 9; Olson, Slater \& Hunt, 2005). Diğer yandan performansı tanımlayan unsurlar, sunulan mal ve hizmetlerin çeşidine göre de değişebilmektedir. Bazı hizmetlerde kalite ön planda yer alırken, bazılarında miktar ön plana çıkabilmektedir. Bazı durumlarda ise performansın unsurları, sunulan mal ve hizmetin kaynağına göre de farklılık gösterebilmektedir (Köseoğlu, 2005: 213). Örneğin, Gooch ve Montgomery üretim gücünün göstergesi olarak 7 anahtar kriteri stok devir oranı, imalat dönem-devir süresi, ürün maliyeti, uluslararası rekabet edebilme gücü, büyüme oranı, pazar payı ve yatırımın getirisi olarak siralamaktadir (Gooch \& Montgomery, 1986: 58). Turizm sektörü açısından bakıldığında, performans ölçütleri olarak pazar payı, satış büyüklüğü, kârlılık oranı, likidite oranı, sermaye yapısı, hizmet kalitesi, kaynak kullanım verimliliği ve personel verimliliği olarak karşımıza çıkabilmektedir (Fitzgerald, Johnson, Brignall, Silvestro \& Voss, 1991). Performans ölçütleri lojistik işletmeler açısından ele alındığında ise bu ölçütler; zamanında teslimat, stok doğruluğu, sipariş hataları, müşteri şikayetleri, sevkiyatların dolar olarak tutarı, geri gelen sipariş miktarı, toplam sipariş çevirim süresi, beklentileri karşılama oranı, karşılanamayan sipariş adedi ve depo çevirim süresi olarak sıralanabilmektedir (Minahan, 1997).

\subsection{Kavramlar Arası Illişkiler ve Araştırmanın Hipotezleri}

Liderlik, bazı araştırmacılar tarafından bir firmanın performansını artırmak için önemli itici güçlerden biri olarak görülmektedir. Etkili liderlik yönetim geliştirmede güçlü bir kaynak ve örgütsel performans iyileştirmede sürdürülebilir rekabet avantaj1 olarak kabul edilmektedir (Zhu, Chew \& Spangler, 2005). Öyle ki Mckay 2008 yllında CEO'ların firma performansı üzerine etkisinin incelendiği çalışmasında CEO'ların davranışları ile firma performansı arasında pozitif yönlü anlamlı bir ilişski saptamıştır. Çalışmada firma performansı üzerinde ki CEO etkisi, firma etkisinden 4 kat, sektör etkisinden ise 5 kat daha büyük olarak hesaplanmıştır (Mckay, 2008). Liderlerin belirlenmiş bir vizyonu ifade etmesi, kurumun başarabileceğini düşündüğü, çekici bir gelecek durumu açılama çabasıdır (Bass, 2008). Bu anlamda vizyon sahibi lider, yüksek yeterliliğe ve başarıya ulaştıracak bir vizyona sahip olduğu izlenimini yaratmak suretiyle, astlarının ortaya konulan hedefleri yerine getirmek için coşku ve bağlılıkla çalışmasını sağlayabilir (Drath, 2001; Avery, 2004).

Dönüşümcü liderlik, paylaşlan bir vizyona tercüman olmak, düşünsel olarak işgörenleri uyarmak, işgörenlerdeki bireysel farklılıkları izlemek konularında liderin yeteneği olarak karakterize edilmektedir (Brown \& Keeping, 2005: 246). İlham alma, motivasyon, meydan okuma, ortak vizyon oluşturma, kişisel gelişim gibi unsurların üzerinde duran (Bass \& Steidlmeier, 1999) dönüşümcü liderler, izleyicilerinin gereksinmelerini, inançlarını ve değer yargılarını değiştirebilen, değişimi ve yenilikçiliği benimseyerek örgütlerini üstün performansa yükseltmeye yönlendirebilen bireylerdir. Bununla birlikte dönüşümcü liderlerin vizyon sahibi olması ve bu vizyonu çalışanlarına da kabul ettirmesi en temel görevlerindendir (Luthans, 1995: 357). Dönüşümcü liderliğin astların memnuniyeti, motivasyonu ve performansı ile pozitif bir şekilde 
ilişkili olduğuna dair kayda değer kanıtlar bulunmaktadır (Bass \& Steidlmeier, 1999).

Wang, Law, Hackett, Wang ve Chen (2005); CEO'ların liderlik davranışları, örgüt performansı ve çalışan tutumları arasındaki ilişkileri inceledikleri çalışmalarında, CEO'ların davranışlarından biri olarak belirledikleri "bir vizyonu ifade etme" ile örgüt performansı arasında pozitif bir ilişki ortaya koymuşlardır. Vizyoner liderlerin yeni örgütsel ortamlarda yüksek seviyelerde sağladıkları uyum, bağlılık, güven, motivasyon sonucu yüksek performansa neden olacağ 1 düşünülmektedir (Zhu vd., 2005). Sully de Luque, Washburn, Waldman ve Ev (2008) yaptıkları çalışmada, bir liderin geleceğin belirleyicisi olan zorlayıcı bir vizyonu hedeflediği durumlarda, takipçilerin bu vizyonu ve onun temsil ettiği değerleri tanımlamak ve gerçekleştirmek isteyeceklerini söylemişlerdir. Böylece astlar vizyonu gerçekleştirmek için kişisel fedakarlıklar yapmaya daha istekli hale gelecek ve kendi kişisel ihtiyaçlarını feda etmeye daha istekli olacaklardır. Sonuç olarak daha fazla çaba harcayacak olan çalışanlar işletme performansının da artmasını sağlayacaklardır. Ashford ve arkadaşları (2016) yaptıkları çalışmada, CEO'lar tarafından ortaya koyulan vizyonu ifadesinin, firma performansı ile ilişkili olup olmadığını araştırmışlardır. Çalışma sonucunda, CEO'lar tarafindan oluşturulan ve açıklanan vizyon ifadelerini firma performansı üzerinde olumlu bir etki yarattığı görülmüştür. Doğanalp (2009)'ın çalışmasında, , banka üst yönetiminin personele kazandırdığı ortak vizyonla personeli yapabileceğini düşündüğünden daha fazlasını yapabileceğine inandırmasının kriz dönemlerinde işletme performansını olumlu yönde etkilediği belirlenmiştir.

H1: Kadın girişimcilerin ortak vizyon yaratma davranışlarl, sahip oldukları işletmelerin performansını pozitif anlamda etkilemektedir.

Duygular, insanları yeterliliklere yönlendirmekte, uygun davranışı teşvik etmekte, bilgiyi süzmeyi ve deneyimi gerçekleştirmeyi sağlamaktadır. (Merlevede, Vandamme \& Bridoux, 2006: 194). Ayrıca davranışları etkileme özelliği ile başkalarından gelen sinyallere cevap vererek, bireye iletişim kurmasında yol gösteren unsurlardır (Goleman, 2007: 50). Günümüz iş dünyası, çok sayıda insanın bir arada ve yüksek etkileşim düzeyinde çalışmalarını gerektirmektedir. Böyle bir ortamda kişinin kendisinin ve başkalarının duygularını yönetebilmesi, diğer insanlarla uyumlu bir şekilde çalışabilmesini sağlayacaktır. Duygusal zeka insanların anlaşılması ve onlara yardım edilmesi yoluyla daha verimli çalıştırılmalarını sağlama konusunda önemli bir role sahiptir
(Grossman, 2000: 19). Duygusal zeka liderlik, zihinsel iyilik hali, fiziksel durum, ilişkileri yönetmek, başarı sağlama ve çatışmaları çözme gibi birçok farklı konuda önemlidir (Scuderi, 2013). Liderler için en zor sorunlardan biri, duygusal zeka becerilerini öğrenme ve bunları kendi şirketlerini yönetme aşamasında kullanabilmeleridir. Elbette ki duygusal zeka liderliğin zorunlu bir belirleyicisi değildir. Ancak duygusal zeka etkin liderlik davranıșlarını, diğer faktörlerle birlikte etkilemektedir (Packard, 2008: 51). Bu anlamda kadın girişimcilerin aynı zamanda liderlik ettikleri işletmelerinde gösterdikleri ortak vizyon yaratma davranışının işletme performansına etkisinde duygusal zekanın etkili olabileceği düşünülmektedir.

H2: Kadın girişimcilerin ortak vizyon yaratma davranışlarının sahip olduklarl işletmelerin performansina etkisinde duygusal zekanın düzenleyici bir rolü vardır.

\section{YÖNTEM}

\subsection{Evren ve Örneklem}

Bu çalışma dahilinde Adana, Mersin, Osmaniye ve Hatay illerinde faaliyet gösteren kadın girişimciler çalışmanın evrenini oluşturmaktadır. Bölgede faaliyet gösteren bütün kadın girişimcilere ulaşmak mümkün olmadığı için, tam sayım yöntemi kullanılamamış, örnekleme yöntemi uygulanmıştır. Bölgedeki Ticaret Odaları, Sanayi Odaları ve Esnaf ve Sanatkarlar Odaları'na kayıtlı kadın girişimcilerin listeleri oluşturulmuş ve bu listelerden basit tesadüfi örnekleme yöntemi ile örneklem belirlenmiştir. Bölgede faaliyet gösteren çeşitli meslek odalarından alınan listelerin incelenmesi ve gerekli araştırmaların yapılması sonucu, birçok kadının bahsi geçen meslek odalarına kayıtlı olmasına rağmen, aktif olarak girişimcilik faaliyetini yerine getirmediği, sadece kağıt üzerinde işletme sahibi olarak görüldüğü anlaşılmıştır. Çalışma kapsamında kadınların girişimci olarak sayılabilmesi için; aktif olarak işin başında olması, çalışanlarına önderlik etmesi ve işlerini bizzat yürütüyor olması gerekmektedir. $\mathrm{Bu}$ nedenle çalışmanın evreni olarak ele alınacak kadın girişimci sayısı tam olarak belirlenememektedir. Bununla birlikte çalışmaya dahil edilen kadın girişimcilerin tamamının, yanlarında en az iki kişi çalıştırıyor olması beklenmiştir. Bu şartlar altında, çalışma kapsamında 773 kadın girişimciye anket uygulanmış, ancak bunlardan 535 tanesi araştırma kapsamında kullanıma uygun bulunmuş ve analize dahil edilmiştir. 


\subsection{Veri Toplama Araçlart}

Araştırma tanımlayıcı türde tasarlanmış olup gerekli veriler, anket yöntemi ile toplanmıştır. Kullanılan anket formu 4 bölümden oluşmaktadır. Birinci bölümde Kouzes ve Posner (2002)'ın liderlik davranışları ölçeği, ikinci bölümde Chan (2004)'in duygusal zeka ölçeği, üçüncü bölümde Zerenler (2005)'in işletme performansı ölçeğinden yararlanılmıştır. Son bölümde ise demografik bilgi formu bulunmaktadır.

Ortak vizyon davranışını belirlemek için Kouzes ve Posner (2002) tarafından geliştirilen, geçerlilik ve güvenirlik çalışması ile Türkçeye uyarlaması Duygulu (2007) tarafindan yapılmış olan Liderlik Davranışları Ölçeği'nin ortak bir vizyon oluşturma ile ilgili 6 maddelik bölümü kullanılmıştır. Ölçek, 5'li Likert tipinde derecelendirilmiş olup, cevap seçenekleri; 1-Hiçbir zaman, 2-Nadiren, 3-Bazen, 4-Çoğunlukla, 5-Her zaman şeklinde puanlandırılmıştır.

Kadın girişimcilerin duygusal zeka boyutlarının değerlendirilmesinde, Chan'in (2004) tükenmişlikle duygusal zeka arasındaki ilişkiyi incelemede kullandığı, ölçekten yararlanılmıştır. Ölçeğin orijinali, Schutte ve arkadaşlarının (1998) 33 maddelik çalışmasından geliştirilmiştir. Ölçek, duygusal değerlendirme, pozitif duygusal yönetim, empatik duyarlılık ve duyguların pozitif kullanımı olmak üzere dört boyuttan ve toplamda 12 maddeden oluşmaktadır. Cevapları 5'li Likert tarzında derecelendirilmiş olmakla birlikte, cevap seçenekleri, 1-Kesinlikle Katılmiyorum, 2Katılmıyorum, 3-Kararsızım, 4- Kat1liyorum, 5Kesinlikle Katılıyorum şeklinde puanlandırılmıştır. İşletme performansının ölçülmesinde Zerenler (2005) tarafindan, Das ve Narasimhan (2001: 521) ile Bititci, Turner ve Begemann (2000: 107) tarafından kullanılan araştırma sorularından faydalanılarak geliştirilmiş olan bir ölçekten yararlanılmıştır (Zerenler, 2005: 23). 7 ifadenin yer aldığı işletme performansı 5'li Likert tipinde derecelendirilmiştir ve cevap seçenekleri; 1Rakiplerimizden çok kötüyüz, 2-Rakiplerimizden kötüyüz, 3-Rakiplerimizden ne iyiyiz ne kötüyüz, 4Rakiplerimizden iyiyiz, 5-Rakiplerimizden çok iyiyiz şeklinde puanlandırılmıştır.

\section{3. Ölçeklerin Geçerlilik ve Güvenilirlik Analizleri}

Araştırmanın temel amaçlarına ulaşmak için yapılacak olan istatistiksel analizler öncesi ölçeklere ait maddeler açıklayıcı faktör analizine (AFA) tabi tutulmuştur. Ölçek verilerinin faktör analizine uygunluğu KMO örneklem yeterliliği ve Barlett küresellik testi ile incelenmiştir. Test sonucunda ortaya çıkacak değer aralıkları; $0,50-0,60$ arası kötü, 0,60-0,70 arası zayıf, 0,70-0,80 arası orta, $0,80-0,90$ arası iyi ve 0,90 üzeri mükemmel olarak yorumlanmaktadır (Çokluk, Şekercioğlu \& Büyüköztürk, 2012: 207). KMO ve Barlett's Küresellik testi değerinin ortak vizyon oluşturma için $(0,887 ; \chi 2=1639,653$ ve $\mathrm{p}<0,0001)$ duygusal zeka için $(0,947 ; \chi 2=3306,414$ ve $p<0,0001)$ ve işletme performansı için $(0,876 ; \chi 2=2163,066 \mathrm{ve}$ $\mathrm{p}<0,0001)$ olması, ölçeklere ilişkin verilerin faktör analizi yapılmasının uygun olduğu göstermektedir. Ortak vizyon oluşturma ölçeğinin tek faktörlü yapısının toplam varyansın \% 64,4'ünü açıkladığı tespit edilmiş olup faktör yüklerinin 0,76 ile 0,83 arasında oluğu görülmüştür. Duygusal zeka ölçeği, 0,50 ortak varyans değerinin altında kalan 11 . madde ölçekten çıkarıldıktan sonra toplam varyansın \%57,32'sini açıkladığı tespit edilen tek boyut oluşturmuştur. Ölçek maddelerin faktör yükleri; en düşük 0,69 , en yüksek ise 0,80 olarak hesaplanmıştır. Son olarak işletme performansı ölçeğinin tek faktörlü yapısının toplam varyansın \% 61,8 'ini açıkladığ 1 belirlenmiştir. Bununla birlikte ölçeğin faktör yüklerinin 0,72 ile 0,85 arasında değiştiği görülmüştür. Ölçeklerin güvenirliğini test etmek amacıyla yaygın şekilde kullanılan Cronbach Alpha katsayısı hesaplanmıştır. Tablo 1'de görüldüğü gibi ortak vizyon oluşturma davranış1 ölçeği, duygusal zeka ölçeği ve işletme performans1 ölçeği için hesaplanan Cronbach Alpha katsayıları sirasiyla $\alpha=0,91 ; \alpha=0,90 ; \alpha=0,92$ 'dir.

Açıklayıcı faktör analizi sonrası yapılan doğrulayıcı faktör analizinde ortak vizyon oluşturma ölçeğinin yapısı doğrulanmıştır (Ki-kare/ df $=3,60$; RMSEA=0,070; NFI=0,99; $\mathrm{CFI}=0,99 ; \mathrm{SRMR}=$ 0,022). Duygusal zeka ölçeğine uygulanan doğrulayıcı faktör analizi sonrası ölçeğin yapısının doğrulandığ1 görülmüştür (Ki-kare/ df $=3,77$; RMSEA=0,075; NFI=0,98; $\mathrm{CFI}=0,99$; $\mathrm{SRMR}=$ 0,34). İşletme performansı ölçeğine uygulanan doğrulayıcı faktör analizi sonrası ise ölçeğin yapısının doğrulandığg1 görülmüştür (Ki-kare/ df =3,76; RMSEA=0,072; NFI= 0,99; $\mathrm{CFI}=0,99$; SRMR= 0,28). Tablo 2'de ölçekler için kabul edilebilir uyum değerleri ve mükemmel uyum değerleri ile birlikte ölçekler ait hesaplanan uyum iyiliği değerleri birlikte verilmiştir.

\section{BULGULAR}

\section{1. Katılımcılara Ait Tanımlayıcı İstatistikler}

Ankete katılan 535 kadın girişimcinin; kadın girişimcilerin \%37'sinin lise mezunu olduğu, \%48,4'ünün 29-38 yaş aras1 grupta olduğu, $\% 75$ 'inin evli olduğu, \%49'unun 6-10 yıl arası 
Tablo 1: Ölçeklerin Faktör Yükleri ve Güvenirlikleri

\begin{tabular}{|c|c|c|c|}
\hline Sorular & $\begin{array}{c}\text { Faktör } \\
\text { Yükü } \\
\text { (AFA) }\end{array}$ & $\begin{array}{l}\text { Faktör } \\
\text { Yükü } \\
\text { (DFA) }\end{array}$ & $\begin{array}{c}\text { Cronbach } \\
\text { Alfa }\end{array}$ \\
\hline \multicolumn{4}{|l|}{ Ortak Vizyon Oluşturma } \\
\hline $\begin{array}{l}\text { Çalışanlarımı işletmenin amaçları doğrultusunda motive } \\
\text { ederim. }\end{array}$ & ,83 & 0,80 & \multirow{6}{*}{$\mathbf{0 , 9 1}$} \\
\hline $\begin{array}{l}\text { Çalışanların, uzun vadeli çıkarları ile işletme hedeflerinin } \\
\text { birlikte gerçekleşebileceğini görmelerini sağlarım }\end{array}$ & ,83 & 0,80 & \\
\hline $\begin{array}{l}\text { Gelecekte yaşayabileceğimiz zorlukları çalışanlarımla } \\
\text { paylaşırım. }\end{array}$ & ,82 & 0,74 & \\
\hline $\begin{array}{l}\text { Gelecekteki eğilimlerin işimizi nasıl etkileyebileceğini } \\
\text { çalışanlarıma açıklarım. }\end{array}$ & ,81 & 0,76 & \\
\hline Gelecekle ilgili olarak iyimserimdir. & ,77 & 0,74 & \\
\hline Gelecekle ilgili hayallerimi çalışanlarımla paylaşırım. & ,76 & 0,66 & \\
\hline \multicolumn{4}{|l|}{ Duygusal Zeka } \\
\hline Duygularımı yaşadıkça onların farkına varırım. & 0,80 & 0,75 & \multirow{11}{*}{$\mathbf{0 , 9 0}$} \\
\hline İnsanların yüzlerine bakarak yaşadıkları duyguları anlarım. & 0,79 & 0,78 & \\
\hline Pozitif bir ruh halindeyken yeni fikirler bulabilirim. & 0,79 & 0,78 & \\
\hline $\begin{array}{l}\text { Pozitif bir ruh halindeyken problem çözmek benim için } \\
\text { kolaydır. }\end{array}$ & 0,79 & 0,77 & \\
\hline Duygularımı yaşayarak kolayca fark ederim & 0,78 & 0,76 & \\
\hline Duygular, yaşamı anlamlı kılan şeylerdendir. & 0,77 & 0,71 & \\
\hline Güzel şeylerin olmasını beklerim. & 0,77 & 0,74 & \\
\hline $\begin{array}{l}\text { Pozitif bir duyguyu yaşarken, onu nasıl sonlandıracağımı } \\
\text { bilirim. }\end{array}$ & 0,73 & 0,69 & \\
\hline Ruh halim değiştiğinde, yeni firsatları fark ederim. & 0,71 & 0,67 & \\
\hline Gönderilen sözsüz mesajları fark ederim. & 0,70 & 0,66 & \\
\hline $\begin{array}{l}\text { Engeller karşısında gayret etmek için kendimi iyi bir ruh } \\
\text { hali içine sokarım. }\end{array}$ & 0,69 & 0,65 & \\
\hline \multicolumn{4}{|l|}{ İșletme Performansı } \\
\hline Rakiplere göre işletmenizin verimliliği & 0,85 & 0,86 & \multirow{7}{*}{0,92} \\
\hline Rakiplere göre işletmenizin satışlar & 0,85 & 0,83 & \\
\hline Rakiplere göre işletmenizin amaçlarına ulaşma düzeyi & 0,80 & 0,75 & \\
\hline Rakiplere göre işletmenizin pazar payı & 0,78 & 0,74 & \\
\hline Rakiplere göre işletmenizin karlılı̆ 1 & 0,77 & 0,73 & \\
\hline Rakiplere göre müşteri memnuniyeti sağlama & 0,73 & 0,61 & \\
\hline Rakiplere göre işletmenizin ürünlerinin kalitesi & 0,72 & 0,58 & \\
\hline
\end{tabular}

zamandır işletme sahibi olarak iş hayatında faaliyet gösterdiği Tablo 3'de görülmektedir.

\section{2. Demografik Özelliklerden Kaynaklanan Farklılıklarının Analizi}

Katılımcıların ortak vizyon oluşturma davranışı ölçeği, duygusal zeka ölçeği ve işletme performansı ölçeğine verdikleri cevapların eğitim durumlarına, yaşlarına ve iş hayatında işletme sahibi olarak geçirdikleri sürelere göre farklılaşıp farklılaşmadığını ölçmek için ANOVA testi, anlamlı farklılıkların hangi gruplardan kaynaklandığını tespit etmek için yapılmış Scheffe testi uygulanmıştır. Tablo 4'te görülen sonuçlara göre;

- Duygusal zeka, ortak vizyon oluşturma davranışı ve işletme performansı eğitim durumuna göre anlamlı farklılık göstermektedir.

- Duygusal zeka ve ortak vizyon oluşturma davranış1, yaş gruplarına göre anlamlı farklılık göstermektedir.

- Duygusal zeka, ortak vizyon oluşturma 
Tablo 2: Ölçeklerin Uyum İyiliği Değerleri

\begin{tabular}{cccccc}
\hline $\begin{array}{c}\text { İndeks } \\
\text { (Uyum } \\
\text { Olçüleri) }\end{array}$ & $\begin{array}{c}\text { Mükemmel Uyum } \\
\text { Değerleri }\end{array}$ & $\begin{array}{c}\text { Kabul Edilebilir } \\
\text { Uyum Değerleri }\end{array}$ & $\begin{array}{c}\text { Ortak Vizyon } \\
\text { Oluşturma }\end{array}$ & $\begin{array}{c}\text { Duygusal } \\
\text { Zeka }\end{array}$ & $\begin{array}{c}\text { İşletme } \\
\text { Performansı }\end{array}$ \\
\hline $\mathbf{X}^{2} / \mathbf{d f}$ & $\leq 2$ & $2 \leq \mathrm{X}^{2} / \mathrm{df} \leq 5$ & 3,60 & 3,77 & 3,76 \\
\hline RMSEA & $0,00 \leq \mathrm{RMSA} \leq 0,05$ & $0,05 \leq \mathrm{RMSA} \leq 10$ & 0,070 & 0,075 & 0,072 \\
\hline SRMR & $0,00 \leq \mathrm{SRMR} \leq 0,05$ & $0,05 \leq \mathrm{SRMR} \leq 0,08$ & 0,022 & 0,34 & 0,28 \\
\hline $\mathbf{N F I}$ & $0,95 \leq \mathrm{NFI} \leq 0,100$ & $0,90 \leq \mathrm{NFI} \leq 0,95$ & 0,99 & 0,98 & 0,99 \\
\hline $\mathbf{C F I}$ & $0,95 \leq \mathrm{CFI} \leq 0,100$ & $0,90 \leq \mathrm{NFI} \leq 0,95$ & 0,99 & 0,99 & 0,99 \\
\hline
\end{tabular}

\begin{tabular}{llllll}
\multicolumn{7}{c}{ Tablo 3: Tanımlayıcı İstatistikler } \\
\hline Ĕ̆itim Düzeyi & $\mathbf{N}$ & $\mathbf{\%}$ & Yas & $\mathbf{N}$ & $\mathbf{\%}$ \\
\hline İlköğretim & 172 & 32.2 & $18-28$ & 83 & 15.5 \\
Lise & 198 & 37 & $29-38$ & 259 & 48,4 \\
Önlisans/Lisans & 129 & 24,1 & $39-48$ & 145 & 27,1 \\
Lisansüstü & 36 & 6,7 & 49 ve üzeri & 48 & 9 \\
\hline Faaliyet Süresi & $\mathbf{N}$ & $\mathbf{\%}$ & Medeni Durum & $\mathbf{N}$ & $\mathbf{\%}$ \\
\hline $0-5$ & 161 & 30.1 & Evli & 401 & 75 \\
6-10 & 262 & 49 & Bekar & 134 & 25 \\
11 ve üzeri & 112 & 20,9 & & & \\
\hline
\end{tabular}

davranışı ve işletme performansı işletme sahibi olarak geçirilen süreye göre anlamlı farkl11ık göstermektedir.

Ortak vizyon oluşturma ölçeği, duygusal zeka ölçeği ve işletme performansı ölçeğine verdikleri cevapların katılımcıların medeni durumuna göre farklılık gösterip göstermediğini belirlemek için $t$ testi yapılmıştır. Tablo 5 incelendiğinde, katılımciların medeni durumuna göre anlamlı farklılık olan tek değişkenin duygusal zeka olduğu görülmüştür. Buna göre bekar olanlar, evli olanlara göre daha yüksek bir duygusal zekaya sahiptirler.

\subsection{Araşturma Modelinin Test Edilmesi}

Etkili liderlik davranışlarından biri olan ortak vizyon oluşturma davranışının işletme performansına etkisinde duygusal zekanın düzenleyici rolü olup olmadığını belirlemek amacıyla hiyerarşik regresyon analizinden faydalanılmıştır.

Hiyerarşik regresyon analizi sonucu, birinci modelde regresyon analizine girilen bağımsız değişken olan ortak vizyon oluşturma ile bağımlı değişken olan işletme performansı, ikinci model ise birinci gruptakilerle birlikte düzenleyici değiş̧ken olan duygusal zeka ve üçüncü modelde ise ortak vizyon oluşturma ile birlikte regresyon analizine dahil edilen ortak vizyon oluşturma ile duygusal zekanın çarpımından oluşan etkileşimsel terimi kapsamaktadır. Tablo 6'da modeller bazında katsayılar incelendiğinde, birinci grupta modele dâhil edilen ortak vizyon oluşturma $(\beta=0,245$; $\mathrm{p}<0,01)$; ikinci grupta modele dahil edilen ortak vizyon oluşturma $(\beta=0,180 ; \quad \mathrm{p}<0,01)$ ile duygusal zeka $(\beta=0,146 ; p<0,01)$; üçüncü grupta ise modele dahil edilen ortak vizyon oluşturma $(\beta=0,180$; $\mathrm{p}<0,01)$ ile duygusal zeka $(\beta=0,150 ; \mathrm{p}<0.01)$ ve duygusal zeka ve ortak vizyon oluşturma etkileşimsel terimi $(\beta=0,068 ; \quad \mathrm{p}<0,01) \quad$ işletme performansı algısı üzerinde anlamlı etkiye sahiptir.

Sonuç olarak hiyerarşik regresyon modelinin bütün aşamaları istatistiksel olarak anlamlıdır. Etkileşimsel terimin bulunmadığ 1 birinci gruptaki ortak vizyon oluşturma $(\mathrm{F}=33,931 ; \mathrm{p}=0,000)$ ve ikinci gruptaki ortak vizyon oluşturma ile duygusal zekanın $(\mathrm{F}=22,143 ; \mathrm{p}=0,000)$ regresyon modeline anlamlı katkı yaptığını göstermektedir. Düzeltilmiş $\mathrm{R}^{2}$ değerleri sırasiyla 0,60 ve $0,77^{\prime}$ dir. $\mathrm{Bu}$ sonuç işletme performansındaki değişimin \%6'lık kısmını ortak vizyon oluşturma, $\% 7,7^{\prime}$ lik kısmını ise ortak vizyon oluşturma ile duygusal zekanın birlikte açıkladığını göstermektedir. İkinci grupta duygusal zeka değişkeninin regresyona girmesi işletme performans1 algisinda \%0,17'lik ilave varyans1 açıklamış ve $\mathrm{R}^{2}$ deki bu değişim anlamlı bulunmuştur $(\mathrm{F}=22,143 ; \mathrm{p}=0,000)$. Yine üçüncü gurupta ortak vizyon oluşturma ile duygusal zeka değişkenlerinin çarpımı olan etkileşimsel terim modele dahil edilmiş ve model istatistiksel olarak anlamlı bulunmuştur $(F=15,699 ; p=0,000)$. Üçüncü 
Tablo 4: Demografik Özelliklerden Kaynaklanan Algı Farklılıklarının Analizi (ANOVA Testi)

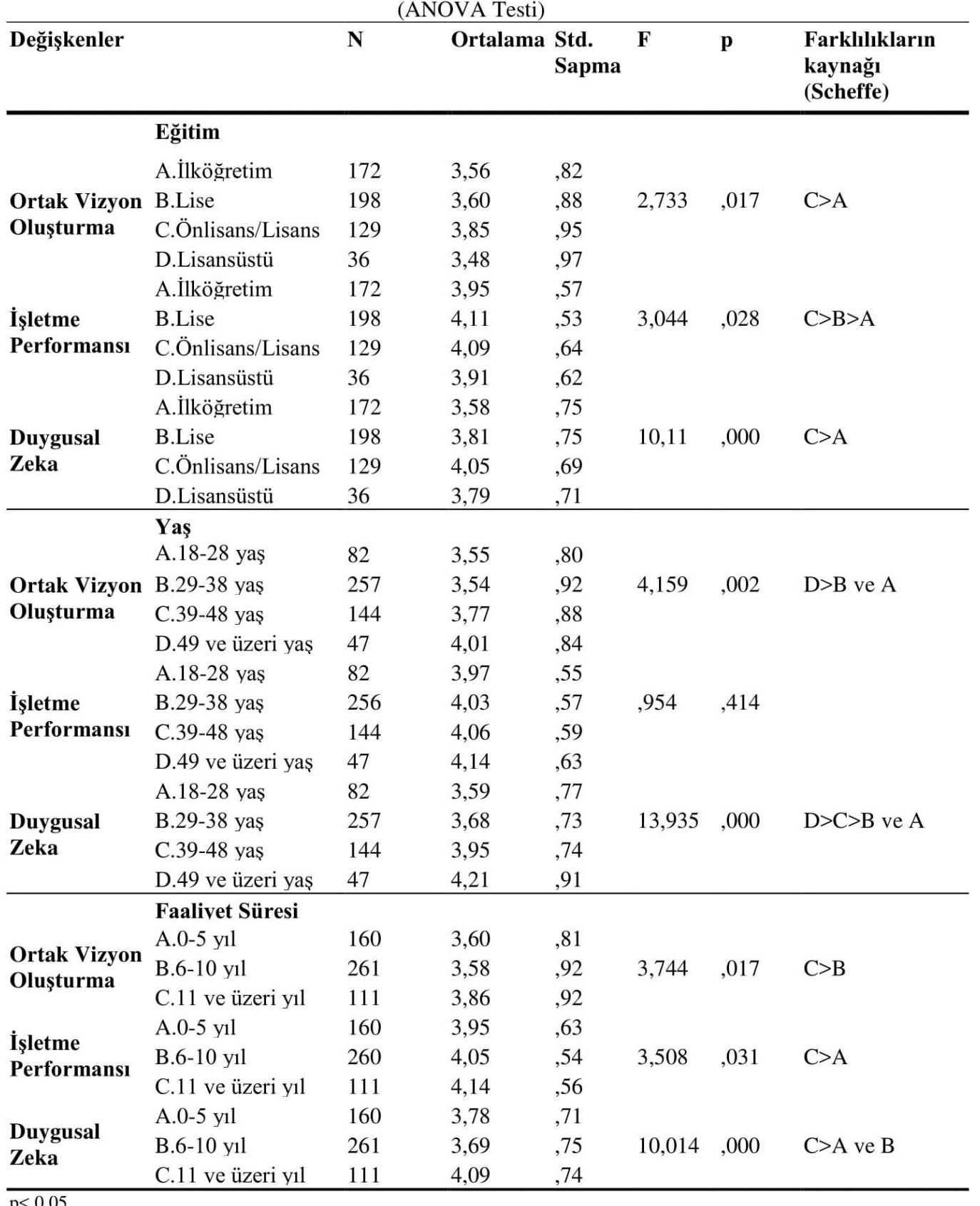

grupta etkileşimsel terimin regresyona girmesi işletme performansında \%0,05'lik ilave varyans açıklamaya katkıda bulunmuştur.

Son olarak ortak vizyon oluşturma algisı ile duygusal zekanın etkileşiminin biçimini ve yönünü belirlemek için, düşük ve yüksek düzeydeki (ortalama değerinden +1 ve -1 standart sapmadaki duygusal zekanın olduğu durumlarda) ortak vizyon oluşturmanın işletme performansı üzerindeki etkisi grafiksel olarak Şekil 1'de gösterilmiştir.

Şekil 1 çalışanların işletme performansları üzerinde ortak vizyon oluşturma ile duygusal zekanın birlikte (etkileşimsel) etkisinin var olduğunu göstermektedir. İşletme performansı ile ortak vizyon oluşturma arasındaki ilişkiyi gösteren Şekil 1' deki eğimlerin, 0 (sıfır) değerinden anlamlı düzeyde farklılaşıp farklılaşmadığı eğim testi (slope test) ile analiz edilmiştir (Aiken \& West, 1991). Bu test çalışanların liderlerin ortak vizyon oluşturması ile işletme performansı tutumları arasındaki ilişkinin duygusal zekaya bağlı olup olmadığını ortaya koymaktadır. Çalışanlarda var olan yüksek düzeydeki duygusal zekâ, ortak vizyon oluşturma ile işletme performansı arasındaki ilişki anlamlı ve pozitif yönlüdür. $\mathrm{Bu}$ sonuçlara göre, ortak vizyon oluşturma ile işletme performansı arasındaki ilişki duygusal zeka tarafindan biçimlenmektedir. Lider 
Tablo 5: Katılımcıların Medeni Durumuna Göre Farklılıklarının Analizi (t testi)

\begin{tabular}{llllllll}
\hline Değişkenler & $\begin{array}{l}\text { Medeni } \\
\text { Durum }\end{array}$ & N & Ortalama & $\begin{array}{l}\text { Std. } \\
\text { Sap. }\end{array}$ & t & F & p \\
\hline Ortak Vizyon & Evli & 397 & 3.58 & 0.93 & -0.122 & 0.414 & 0.903 \\
Oluşturma & Bekar & 131 & 3,60 & 0,99 & & & \\
\hline & Evli & 397 & 3,74 & 0,76 & $-3,312$ & 0,267 & 0,001 \\
Duygusal Zeka & Bekar & 131 & 3,98 & 0,68 & & & \\
\hline & Evli & 397 & 4,07 & 0,57 & $-0,762$ & 0,008 & 0,079 \\
İșletme & Bekar & 130 & 3,96 & 0,60 & & & \\
\hline p<0,05 & & & & & & &
\end{tabular}

Tablo 6: Hiyerarşik Regresyon Analizi

\begin{tabular}{|c|c|c|c|c|c|}
\hline \multirow[t]{2}{*}{ Model } & \multicolumn{4}{|c|}{ Regresyon Katsayıları } & \multirow[t]{2}{*}{ Model İstatistikleri } \\
\hline & B & S.H. & $\beta$ & $\mathbf{t}$ & \\
\hline $\begin{array}{l}1 \text { (Sabit) } \\
\text { Ortak Vizyon }\end{array}$ & $\begin{array}{l}4,043 \\
0,141\end{array}$ & $\begin{array}{l}0,024 \\
0,024\end{array}$ & $0,245^{*}$ & $\begin{array}{l}167,442 \\
5,825\end{array}$ & $\begin{array}{l}R=0,245 ; R^{2}=0,060 \\
F=33,931 ; p=0,000\end{array}$ \\
\hline 2 (Sabit) & 4,043 & 0,131 & & 168,819 & \multirow[b]{2}{*}{$\begin{array}{l}\mathrm{R}=0,277 ; \mathrm{R}^{2}=0,077 ; \\
\mathrm{F}=22,143 ; \mathrm{p}=0,000\end{array}$} \\
\hline $\begin{array}{l}\text { Ortak Vizyon } \\
\text { Duygusal Zeka }\end{array}$ & $\begin{array}{l}0,180 \\
0,146\end{array}$ & $\begin{array}{l}0,028 \\
0,036\end{array}$ & $\begin{array}{l}0,180^{*} \\
0,146^{*}\end{array}$ & $\begin{array}{l}3,871 \\
3,130\end{array}$ & \\
\hline 3 (Sabit) & 4,025 & 0,026 & & 154,328 & \multirow{3}{*}{$\begin{array}{l}R=0,286 ; R^{2}=0,082 ; \\
F=15,699 ; p=0,000\end{array}$} \\
\hline $\begin{array}{l}\text { Ortak Vizyon } \\
\text { Duygusal Zeka }\end{array}$ & $\begin{array}{l}0,103 \\
0,86\end{array}$ & $\begin{array}{l}0,027 \\
0,027\end{array}$ & $\begin{array}{l}0,180^{*} \\
0,150^{*}\end{array}$ & $\begin{array}{l}3,869 \\
3,225\end{array}$ & \\
\hline Etkileşim & 0,038 & 0,023 & $0,068^{*}$ & 1,634 & \\
\hline
\end{tabular}

$\mathrm{p}<0,01$ düzeyinde anlamlıdır.

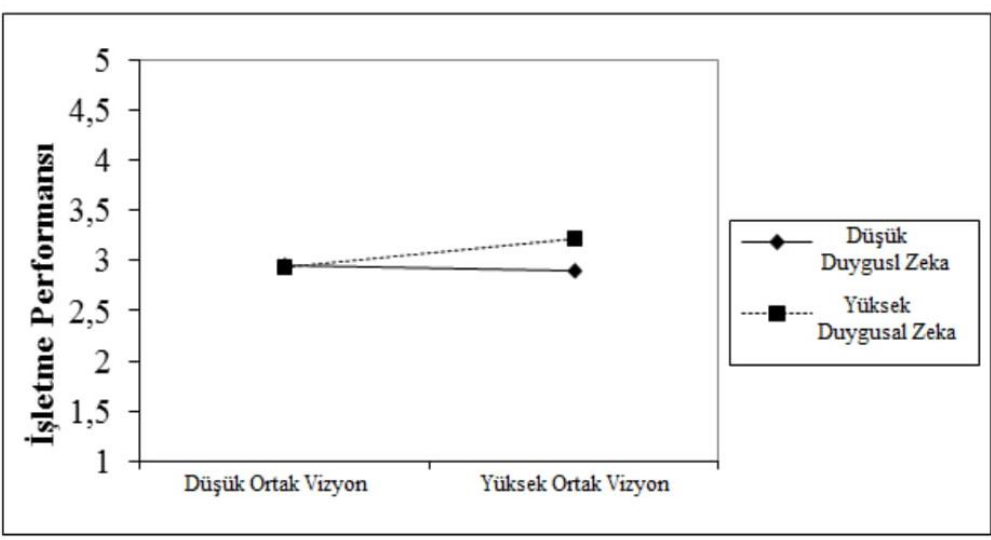

Şekil 1: Ortak Vizyon Oluşturmanın İşletme Performansı Üzerindeki Etkisi 
tarafindan oluşturulan ortak vizyon ile birlikte işletme performansı artış göstermektedir.

\section{TARTIŞMA ve SONUÇ}

Çalışmanın kapsamında; etkili liderlik davranışlarından biri olan ortak vizyon oluşturma davranışının işletme performansına etkisi ile bu etkide duygusal zekanın düzenleyici rolü araştırılmıştır. Kadın girişimimciler üzerine yapılan çalışmada, 535 anket araştırma kapsamında kullanıma uygun bulunmuş ve analize tabi tutulmuştur. Araştırma sonucunda, ortak vizyon oluşturma davranışının işletme performansı üzerinde pozitif bir etkiye sahip olduğu ve bu etki üzerinde duygusal zekanın düzenleyici bir rolü olduğu tespit edilmiştir.

Etkili liderlik davranışlarından biri kabul edilen ortak vizyon oluşturma davranışı, liderin ve örgütün başarılı olması için ortak amaçlar doğrultusunda herkesin benimseyeceği bir vizyon oluşturma, bu vizyonu izleyicilerine kabul ettirme ve uygulanmasını sağlama anlamına gelmektedir (Kouzes \& Posner, 2002). Ortak bir örgüt vizyonu, adaptasyon ve esnekliği arttırarak örgütsel etkinliğin artmasına katkı sağladığı gibi Bennis ve Nanus (1985); performansı iyileştirme, değişimi teşvik etme, stratejik bir plan için temel oluşturma, bireyleri motive etme ve kararlar için bir bağlam sağlama gibi sebeplerden dolayı kurumlar üzerinde geniş kapsamlı bir olumlu etkiye sahiptir (Lipton, 1996). Gerçekliğin paylaşılan gerçek bir vizyonla ortaya konması, çalışanları gelişmek ve öğrenmek için kişisel inisiyatif kazanmaya teşvik edecek ve sonuçta rekabet avantajını geliştirme firsatını artıracak motive edici bir güç sağlayacaktır. Dahası, takipçiler lider tarafından paylaşılmış olan ortak vizyona duygusal olarak bağlı olduklarında, örgütlerinin büyümesini ve ilerlemesini sağlayacak bir şeye gönüllü olarak ve yürekten isteyerek destek olacaklardır (Nanus, 1992). Vizyonun kuruluşun merkezi amacinı ve hedeflerini yansıması ve takipçilerin hangi davranışların önemli, uygun veya önemsiz olduğunu belirlemelerine yardımcı olması çalışanların işlerini daha iyi yapmalarını da sağlayacaktır (Kantabutra \& Avery, 2010). Bu anlamda ortak vizyon oluşturma davranışı ile işletme performansı arasında ilişki olduğu düşünülmüştür. Çalışma kapsamında yapılan analiz sonuçları literatürler benzerlik göstermiş olup, kadın girişimcilerin ortak vizyon yaratma davranışlarının, sahip oldukları işletmelerin performansını pozitif anlamda etkilediği tespit edilmiştir (Bernhard \& O’Driscoll, 2011; Jing, Avery \& Bergsteiner, 2014; Wadhwa \& Parimoo, 2016; Ashford vd., 2016). Ortak bir vizyonun gerekliliği ve bu vizyonun çalıșanlar tarafından paylaşılması işletmelerde motivasyon, bağlılık, işten ayrılma niyeti, örgüt iklimi ve kültürü gibi birçok konuda önemli olduğu gibi işletme performansı açısından da önemli olduğu çalışma sonucunda ortaya konmuştur. İşletme içerisinde bir vizyon oluşturma ve yöneticilerin bu vizyon doğrultusunda çalışanlarını yöneltmesi işletme performansının artmasına katkı sağladığ görülmüş̧ür. $\mathrm{Bu}$ anlamda yöneticilerin bir vizyon oluşturmaları, oluşturdukları vizyonu uygulamaları ve çalışanlarını bu vizyona inandırmaları çok önemli olduğu düşünülmektedir.

Duygusal zeka, bir bireyin duygularla başa çıkma konusundaki yeterliliği ile ilgilidir ve kendi duyguları değerlendirme ve ifade etme, başkalarının duygularını değerlendirme ve tanıma, performansı kolaylaştırmak için duyguları kullanma ile benlikte var olan duyguyu düzenlemeyi içermektedir (Mayer, Salovey \& Caruso, 2000). Duygusal zekası yüksek olan bireyler, duyguları ve duyguları tanımlayabilir, ifade edebilir ve anlayabilir, ayrıca olumsuz duyguları kendi başlarına düzenleyebilir (Ouyang vd., 2015). Diğer insanlara karşı duygusal olan önermelerin kullanılması, sosyal etkileşimin gerekli bir bileşeni olmakla birlikte, olumlu duyguların gösterilmesinin işyerinde yüksek başarı olasılığı ile ilişkili olduğu düşünülmektedir (Ashkanasy \& Hooper, 1999). Özellikle duygusal olarak zeki olan liderlerin bireysel ve örgütsel performansın artmasına katkıda bulunduğu çeşitli araştırmalar ile ortaya konmuştur (Wong \& Kanun, 2002; Goleman, Boyatzis \& McKee , 2002; Prati vd., 2003; Carmeli, 2003). Çalışma dahilinde kadın girişimcilerin liderlikte kullandıkları ortak vizyon oluşturma davranışının işletme performansına etkisinde duygusal zekanın düzenleyici rolü araştırılmış olup, ortak vizyon oluşturma davranışının işletme performansına etkisini duygusal zekanın az da olsa arttırdığı görülmüştür. İnsanları ortak bir amaca inandırma onları bu doğrultuda harekete geçmelerini sağlama anlamına gelen ortak vizon oluşturma davranışının işletme performansına etkisinde duygusal zekanın rolü olması anlaşılabilir ve beklenen bir durumdur. Çünkü duygusal zekaya sahip, kadın girişimcilerin; işlerini iyi yapabilme yeteneklerinin, işlerini yapmadaki esnekliklerinin, yenilik yapma ve insiyatif kullanma becerilerinin ve en önemlisi insanları ikna etme ve bir amaca yönlendirme kabiliyetlerinin yüksek olması kaçınılmazdır. Bu da ortak vizyon oluşturma davranışına sahip kadın girişimcilerin sahip oldukları işletmelerin performanslarına olan etkisinde duygusal zekanın rolünün varlığını anlamlı kılmaktadır.

İşletme sahiplerinin veya yöneticilerinin en önemli görevi işletmenin karlılığını sağlamaktır. $\mathrm{Bu}$ da 
ancak performansı yüksek bir işletme ile mümkündür. Yüksek performansa ulaşmanın bir belirleyicisi de ortak vizyon oluşturma davranışı olduğunun bilincinde olan yöneticilere, işletmenin amaç e hedefleri ile varlık sebebine uygun bir vizyon ifadesi geliştirmeleri tavsiye edilmektedir. Bununla birlikte bu vizyon ifadesinin çalışanlar tarafindan kabul edilmesini ve uygulanmasını sağlayacak, eğitimlere ve motivasyon arttırıcı uygulamalara özen göstermesi önerilmektedir. Bununla birlikte vizyon ifadesi oluşturulurken astlarının fikirlerini alarak, oluşturulan vizyona ortak etmesi de oldukça önemlidir. Çalışma kapsamında duygusal zekanın önemi de görülmüştür. Ortak vizyon davranışının varlığının duygusal zekanın daha yüksek olduğu durumlarda işletme performansına daha fazla katkı sağladığı ortaya konmuştur. Duygusal zekayı bilişsel zekadan ayıran en temel unsur geliştirilebilir olmasıdır. $\mathrm{Bu}$ anlamda işletme içinde liderlik yapan girişimcilere veya yöneticilere; kendini tanımaya zaman ayırma, iletişim ve eleştiriye açık olma, duygularını kontrol altına almayı öğrenme gibi yöntemlerle duygusal zekalarını yükseltmeleri önerilmektedir.

Çalışmada işletme performansı değişkenini ölçmek için, anket maddelerinden yararlanılmış ve katılımcıların kendi işletmelerini değerlendirmeleri istenmiştir. Katılımcıların bu konuda objektif bir değerlendirme yapmamış olma ihtimalleri çalışmanın en temel kısıtıdır. Bundan sonra yapılacak çalışmalarda performansa ilişkin bilgilerin resmi kayitlardan elde edilmesi önerilmektedir.

Çalışma yalnızca kadın girişimcilere uygulanmıştır. Ancak bundan sonra yapılacak çalışmalarda kadın girişimcilerin bu özelliklerinin, erkek girişimcilerle birlikte incelenmesi konu ile ilgili karşılaştırma imkanı sağlayabilecektir.

Araştırma genel olarak benzer bölgelerden gelen, benzer kültürel özelliklere sahip kadın girişimcilerle sınırlıdır. Bundan sonra yapılacak çalıșmaların farklı kültürlerde gerçekleştirilmesi literatüre yeni bir bakış açısı sunabilecek sonuçların elde edilmesine olanak sağlayacaktır. Ayrıca araştırmaya katılan kadın girişimciler, ülke genelinde olduğu gibi genellikle mikro ve küçük ölçekli işletme sahibi kadınlardır. Konuyla ilgili daha sonra yapılacak çalışmalarda büyük ölçekli işletme sahibi olan kadın girişimcilerin de çalışmalara dahil edilmesi, karşılaştırma imkanı sunacağı gibi; daha çok çalışana sahip olması nedeniyle liderlikte ortak vizyon oluşturma davranışının daha etkin bir şekilde anlaşılabilmesini sağlayacaktır.

Son olarak çalışmada yalnızca işletme sahipleri, katılımcı olarak kabul edilmiștir. Daha sonraki çalışmalarda farklı düzeylerde faaliyet gösteren yöneticilerin de çalışmaya katılması ve karşılaştırılmalı sonuçların incelenmesi önerilmektedir. 


\section{KAYNAKÇA}

Acar, F. (2002). Duygusal zeka ve liderlik. Erciyes Üniversitesi Sosyal Bilimler Enstitüsü Dergisi, 12, 53-68.

Aiken, L. S. \& West, S. G. (1991). Multiple regression: Testing and interpreting interactions. Newbury Park, CA: Sage.

Akal, Z. (1998). İşletmelerde performans ölçüm ve denetimi: Çok yönlü performans göstergeleri (3. basım). Ankara: Milli Prokdüvite Merkezi Yayınları.

Akgemci, T. (2008). Stratejik yönetim (2. basim). Ankara: Gazi Kitabevi.

Aldea, M. A. \& Rice, K. G. (2006). The role of emotional dysregulation in perfectionism and psychological distress. Journal of Counseling Psychology, 53, 498510.

Alumran, J. \& Punamäki, R. (2008). Relationship between gender, age, academic achievement, emotional intelligence, and coping styles in Bahraini adolescents. Individual Differences Research, 6, 104119.

Andersen, J. A. (2006). Leadership, personality and effectiveness. The Journal of Socio-Economics, 35, 1078-1091.

Apaydın, F. (2007). Örgütlerde kurumsallaşma ve adaptif yeteneklerin pazarlama eylemlerine ve örgütsel performansa etkileri (Yayınlanmamıs Doktora Tezi). Gebze Yüksek Teknoloji Enstitüsü, Kocaeli.

Ashford, S. J., Wellman, N., Sully de Luque, M., De Stobbeleir, K. E. \& Wollan, M. (2016). Two roads to effectiveness: CEO feedback seeking, vision articulation, and firm performance. Journal of Organizational Behavior, 39 (1), 82-95.

Ashkanasy, N. M. \& Hooper, G. (1999). Perceiving and managing emotion in the workplace: A research agendabased on neurophysiology. Paper presented at the Third Australian Industrial and Organizational Psychology Conference, Brisbane, June, 1999.

Avery, G. C. (2004).Understanding leadership: Paradigms and cases. London: Sage

Baltaş, Z. (2011). Insanın dünyasını aydınlatan ve işine yansıyan ışık duygusal zeka (4. basım). İstanbul: Remzi Kitabevi.

Bass, B. M. \& Avolio, B. J. (1994). Improving Organizational Effectiveness through Transformational Leadership. Thousand Oaks, CA: Sage Publications.

Bass, B. M. (2008). The Bass handbook of leadership (4th ed.). New York: Free Press.
Bass, B. M. \& Steidlmeier, P. (1999). Ethics, character, and authentic transformational leadership behavior. Leadership Quarterly, 10, 181-217

Bass, B. M. (1985). Leadership and performance beyond expectations. New York: The Free Pres.

Bass, B. M. (1990). Bass and Stogdill's handbook of leadership, theory, research, and managerial applications (3th ed.). New York: The Free Press.

Bennis, W. \& Nanus, B. (1985). Leaders, the strategies for taking charge. New York: Harper and Rowe.

Bernhard, F. \& O' Driscoll, M. P. (2011). Psychological ownership in small family-owned businesses: Leadership style and nonfamily-employees' work attitudes and behaviors. Group \& Organization Management, 36(3), 345-384.

Bersin, J. (2012). It's not the CEO, it's the leadership strategy that matters. Retriewed 06.12.2014 from http://www.forbes.com/sites/joshbersin/2012/07/30/it s-not-the-ceo-its-the-leadership-strategy-that-matters/.

Bititci, U. S., Turner, U. \& Begemann, C. (2000). Dynamics of performance measurement systems. International Journal of Operations \& Production Management, 20(6), 692-704

Brown, D. J. \& Keeping, L. M. (2005). Elaborating the construct of transformational leadership: The role of affect. The Leadership Quarterly, 16(2), 245-272.

Carmeli, A. (2003). The relationship between emotional intelligence and work attitudes, behavior and outcomes: An examination among senior managers. Journal of Managerial Psychology, 18(8), 788-813

Carton, A. M., Murphy, C. \& Clark, J. (2014). Vision and Values. In Academy of Management Proceedings (Vol. 2014, No. 1, p. 16842). Briarcliff Manor, NY 10510: Academy of Management.

Chan, D. W. (2004). Perceived emotional intelligence and self-efficacy among Chinese secondary school teachers in Hong Kong. Personality and Individual Differences, 36, 1781-1795.

Chemers M. (1997), An integrative theory of leadership. NewJersey: Lawrence Erlbaum Associates, Publishers.

Cherniss, C. \& Goleman, D. (2001). The emotionally intelligent workplace: How to select for, measure, and improve the emotional intelligence in individuals, groups and organizations. San Francisco: JosseyBass.

Cokins G. (2004). Performance management: Finding the missing pieces (to close the intelligence gap). USA: John Wiley \& Sons Inc. 
Cooper, K. R. \& Sawaf, A. (2010). Liderlikte duygusal zeka (çev: B. Sancar ve Z. B. Ayman). İstanbul: Sistem Yayıncılık.

Çokluk, Ö., Şekercioğlu, G. \& Büyüköztürk, Ş. (2012). Sosyal bilimler için çok değişkenli SPSS ve LISREL uygulamaları. Ankara: Pegem A Yayıncılık.

Das, A. \& Narasimhan, R. (2001). Process-technology fit and its implications for manufacturing performance. Journal of Operations Management, 19(5), 521-540.

Demirkaya, H. (2000). Performans ölçüm rehberi. Ankara: Sayıştay Yayınları.

Denison, D. R. \& Mishra, A. K. (1995). Toward a theory of organizational culture and effectiveness. Organization Science, 6(2), 204-223.

Derue, D. S., Nahrgang, J. D., Wellman, N. E. D. \& Humphrey, S. E. (2011). Trait and behavioral theories of leadership: An integration and meta-analytic test of their relative validity. Personnel psychology, 64(1), 7 52 .

Dhillon, P. K. (1993). Women entrepreneurs: Problems ve prospects. New Delhi : Blaze Publishers ve Distributors.

Doğan, S. (2001). Vizyona dayalı liderlik. İstanbul: Seçil Ofset.

Doğanalp, B. (2009). Kriz döneminde transformasyonel lider davranışlarının işletme performansı bağlamında firsat yönetimine etkisi: Bankacılık sektöründe bir uygulama. Selçuk Üniversitesi Sosyal Bilimler Enstitüsü Dergisi, (22), 131-146.

Drath, W. (2001). The deep blue sea: Rethinking the source of leadership. San Francisco, CA: JosseyBass.

Duygulu, S. (2007). Servis sorumlu hemşirelerine yönelik hazırlanan transformasyonel liderlik eğitim programının liderlik uygulamaları üzerine etkisi (Yayınlanmamış Doktora Tezi). Hacettepe Üniversitesi, Ankara.

Emrem, E. (2002). Strateji Odakl Organizasyonel Performans Yönetim Sistemi Kapsaminda Entelektüel Sermaye Performansının Ölçümü (Yayımlanmamış doktora tezi). Sakarya Üniversitesi Sosyal Bilimler Enstitüsü, Sakarya.

Evans, M. D. R. \& Kelley, J. (2008). Trends in Women's Labor Force Particitation in Australia: 1984-2002. Social Science Research, 37 (1), 287-310.

Fisher, C.J. (1997). Corporate culture and perceived business performance: a study of the relationship between the culture of an organization and perceptions of its financial and qualitative performance (Unpublished doctoral dissertation). California School of Professional Psychology, USA.
Fitzgerald, L., Johnson, R., Brignall, S. Silvestro, R. \& Voss C. (1991). Performance measurement in service businesses. London: CIMA Press,

Goleman, D. (2007). Duygusal zeka: EQ neden IQ'dan önemlidir? (31. basım). (B. S. Yüksel, Çev.) İstanbul: Varlık Yayınları.

Goleman, D., Boyatzis, R. \& McKee, A. (2002). Primal leadership: Realizing the power of emotional intelligence. Boston, MA: Harvard Business Press Books.

Gooch, J. \& Montgomery, M. G. (1986). American can compete. Dallas: Southern Methodist University Press.

Grady, M. W. (1991). Performance measurement: implementing strategy. Strategic Finance, 72(12), 49.

Greenberg, J. (2002). Managing behavior in organizations, Third Edition. New Jersey: Prentice Hall.

Grossman, R. J. (2000). Emotions at work. Health Forum Journal, 43(5), 18-27.

Hicks, H. G. \& Gullett, C. R. (1981). Organizasyonlar; teori ve davranış. (B. Baykal, çev.). İstanbul: İstanbul Üniversitesi İşletme Bilimleri Enstitüsü Yayını. http://www.tbmm.gov.tr/komisyon/kefe/docs/komisy on_raporu_2014_1.pdf Erişim Tarihi: 15.01.204 https://www.academia.edu/4872142/The_rare_Jewel_ of_effective_leadership

Jing, F. F., Avery, G. C. \& Bergsteiner, H. (2014). Enhancing performance in small professional firms through vision communication and sharing. Asia Pacific Journal of Management, 31(2), 599-620.

Kadın Erkek Fırsat Eşitliği Komisyonu (2013). Her alandaki kadın istihdamının artırılması ve çözüm önerileri komisyon raporu. Kadın Erkek Fırsat Eşitliği Komisyonu Yayınları No: 12.

Kantabutra, S. \& Avery, G. C. (2010). The power of vision: statements that resonate. Journal of Business Strategy, 31(1), 37-45.

Karakaş, B. \& Ak, R. (2003). Kamu kurumlarında performans yönetimi önemli midir? Катu Yönetiminde Kalite 3. Ulusal Kongresi, TODAİE Yayın1, Ankara, 337-351.

Konrad, S. \& Hendl, C. (2005). Duygularla güçlenmek (M. Taştan Çev.). İstanbul: Hayat Yayınları.

Kouzes, J. M. \& Posner, B. Z. (2002). The leadership challenge ( $3 r d$ ed.). San Francisco:-Bass.

Köseoğlu, Ö., (2005). Belediyelerde performans yönetimi. Türk İdare Dergisi, 447, 211-234. 
Lipton, M. (1996). Demystifying the development of an organizational vision. Sloan Management Review, 37(4), 83-91.

Luthans, F. (1995). Organizational behavior (7th ed.). İstanbul: Literatür Yayıncıllk.

Mayer, J. D. \& Salovey, P. (1993). The intelligence of emotional intelligence. Intelligence, 17 (4), 432-442.

Mayer, J. D., Salovey, P. \& Caruso, D. (2000). Emotional intelligence as zeitgeist, as personality, and as a mental ability. In R. Bar-On \& J.D.A. Parker (Eds.), The handbook of emotional intelligence (pp. 92-117). San Francisco: Jossey-Bass.

Mboko, S. \& Smith-Hunter A. E. (2009). Women entrepreneurs in Zimbabwe: A case study. The Journal of Global Business Issues, 3(1), 157-169.

Mckay, A. (2008). The effect of CEOs on firm performance. Strategic Management Journal, 29(12), $1357-1367$

Merlevede, E. P., Vandamme, R. \& Bridoux, D. (2006). 7 adımda duygusal zeka. İstanbul: Omega Yayıncılık.

Minahan, T. (1997, January). Are buyers gumming up the supply chain? Purchasing, 122(1), 79-80.

Mutlu, H. M. (2007). Dağıtım kanallarında kanal üyelerinin rol performansinı etkileyen etmenler üzerine bir inceleme (Yayınlanmamış Doktora Tezi). Gebze Yüksek Teknoloji Enstitüsü, Kocaeli.

Nanus, B. (1992). Visionary Leadership: Creating a Compelling Sense of Direction for Your Organization. Jossey-Bass Inc., 350 Sansome Street, San Francisco, CA 94104-1310.

Olson, E. M., Slater, S. F. \& Hult, G. T. M. (2005). The performance implications of fit among business strategy, marketing organization structure, and strategic behavior. Journal of Marketing, 69(3), 4965.

Ouyang, Z., Sang, J., Li, P. \& Peng, J. (2015). Organizational justice and job insecurity as mediators of the effect of emotional intelligence on job satisfaction: A study from China. Personality and Individual Differences, 76, 147-152.

Packard, J. A. (2008). Analyzing the intersection of leadership practices, emotional intelligence, and coping responses in women-owned small businesses (Doctoral dissertation). Capella University, Minneapolis.

Pawar B. S. \& Eastman, K. K. (1997). The nature and implications of contextual influences on transformational leadership: A conceptual examination. Academy of Management Review, 22(1), 80-109.
Peker, E. \& Kubar, Y. (2012). Türkiye'de Kirsal kesimde kadın istihdamına genel bir bakış. Afyon Kocatepe Üniversitesi İ̈BF Dergisi,14(2), 173-188.

Podolny, J. M., Khurana, R. \& Hill-Popper, M. (2005). Revisiting the meaning of leadership. Research in Organizational Behavior, 26, 1-36.

Porter, M. E. (1991). Towards a dynamic theory of strategy. Strategic Management Journal, 12(2), 95117.

Prati, M. L., Douglas, C., Ferris, G. R., Ammeter, A. P. \& Buckley, M. R. (2003). Emotional intelligence, leadership effectiveness, and team outcomes. The International Journal of Organizational Analysis, 11(1), 21-40.

Scuderi, R. (2013). Emotional intelligence - Why is it important? Retrieved 25.09.2014 from http://www.lifehack.org/articles/communication/emot ional-intelligence-why-important.html.

Schutte, N. S., Malouff, J. M., Hall, L. E., Haggerty, D. J., Cooper, J. T., Golden, C. J. \& Dornheim, L. (1998). Development and validation of a measure of emotional intelligence. Personality and Individual Differences, 25, 167-177.

Sichone, B. (2004). The rare jewel of effective leadership: Being the need of the times. Retrieved November 15, 2014, from https://www.academia.edu/4872142/The_ rare_Jewel_of_effective_leadership

Sully de Luque, M. S., Washburn, N. T., Waldman, D. A. \& House, R. J. (2008). Unrequited profit: How stakeholder and economic values relate to subordinates' perceptions of leadership and firm performance. Administrative Science Quarterly, 53, 626-654.

Tichy, N. M. \& Devanna, M. A. (1986). The transformational leader. New York: Wiley.

Venkatraman, N. \& Ramanujam, V. (1986). Measurement of business performance in strategy research: A comparison of approaches. Academy of management review, 11(4), 801-814.

Wadhwa, S. \& Parimoo, D. (2016). Impact of vision and mission on organizational performance in Indian context. The International Journal of Business \& Management (4)12, 165-170.

Wang, H., Law, K. S., Hackett, R. D., Wang, D. \& Chen, Z. X. (2005). Leader-member exchange as a mediator of the relationship between transformational leadership and followers' performance and organizational citizenship behavior. Academy of Management Journal, 48, 420-432. 
Waring, A. L. (2003). African-American female college presidents: Self conceptions of leadership. Journal of Leadership ve Organizational Studies, 9(3), 31-44.

Werner, I. (1993). Liderlik ve yönetim. (V. Üner, Çev.). İstanbul: Rota Yayınevi.

Wong, C. S. \& Law, K. S. (2002). The effects of leader and follower emotional intelligence on performance and attitude: An exploratory study. The leadership quarterly, 13(3), 243-274.

Yeşilyaprak, B. (2001). Duygusal zeka (EQ): $\dot{I}_{S ̧}$ performansını belirleyici bir değişken. Ankara: İmge Kitabevi.

Yukl, G. A. (1989). Leadership in organizations (2nd ed.). New Jersey: Prentice Hall.

Zerenler, M. (2005). Performans ölçüm sistemleri tasarımı ve üretim sistemlerinin performansının ölçümüne yönelik bir araştırma. Ekonomik ve Sosyal Araştırmalar Dergisi, 1, 1-36.

Zhu, W., Chew, I.K.H. \& Spangler, W.D. (2005) CEO transformational leadership ve organizational outcomes: The mediating role of human-capitalenhancing human resource management. The Leadership Quarterly, 16(1), 39-52. 